Article

\title{
Investigation of the Use of Low Temperature Geothermal Organic Rankine Cycle Engine in an Autonomous Polygeneration Microgrid
}

\author{
George Kyriakarakos*(D), Erika Ntavou $(\mathbb{D}$ and Dimitris Manolakos \\ Department of Natural Resources and Agricultural Engineering, Agricultural University of Athens, \\ 75 Iera Odos Street, GR 11855 Athens, Greece; edavou@aua.gr (E.N.); dman@aua.gr (D.M.) \\ * Correspondence: gk@aua.gr
}

Received: 19 November 2020; Accepted: 10 December 2020; Published: 15 December 2020

\begin{abstract}
Low-enthalpy geothermal resources $\left(<150{ }^{\circ} \mathrm{C}\right)$ can be used for electricity generation and are widespread around the world, occurring at shallow depths. At the same time, in many parts of the world, there are existing low-enthalpy geothermal wells that are used for a multitude of applications such as for buildings' heating and agriculture-related applications. The dominant technology to convert low-grade heat $\left(<150^{\circ} \mathrm{C}\right)$ to electricity is the Organic Rankine Cycle (ORC). The autonomous polygeneration microgrid (APM) concept aims to holistically meet in a sustainable way the needs of an off-grid community in terms of electrical loads, space heating and cooling, potable water production through desalination, and the use of hydrogen as fuel for transportation, in the most cost-effective manner possible. Photovoltaics (PVs) and wind turbines have been investigated extensively, since PVs can be installed practically anywhere in the world and wind turbines in areas with sufficient wind potential. The aim of this paper is to investigate techno-economically the potential of utilizing low-enthalpy geothermal resources in small-scale APMs through an ORC engine to fully satisfy the needs of small settlements. In order to accomplish this task with confidence, a case study for the Greek island of Milos has been developed and a typical settlement has been considered. It is worth mentioning that experimental results from a realized low-power $\left(<10 \mathrm{~kW}_{\mathrm{e}}\right)$ ORC engine manufactured to operate at temperatures up to $140{ }^{\circ} \mathrm{C}$ are used to add reliability in the calculations. In order to meet the needs of the people, four different APMs based on PVs, wind turbines, and geothermal ORC of different but appropriate configurations were designed and sized through optimization. The optimization process was based on particle swarm optimization (PSO). The comparative examination of the results shows that the use of a low-power, low-temperature ORC engine in an APM is technically feasible; more cost effective than the configurations based on PVs, wind turbines, or combination of both; and has increased environmental sustainability.
\end{abstract}

Keywords: ORC; geothermal energy; microgrids; polygeneration; particle swarm optimization; energy communities

\section{Introduction}

The current paper investigates techno-economically the use of small-scale $\left(<15 \mathrm{~kW}_{\mathrm{e}}\right)$ low-temperature $\left(<150^{\circ} \mathrm{C}\right)$ geothermal Organic Rankine Cycle (ORC) technology for polygeneration microgrids in order to fully cover essential energy needs of small settlements. The investigation aims at concluding whether geothermal ORC in microgrid concept integration is technically feasible, cost effective, and attractive for future investments, thus constituting an alternative solution to the commonly applied photovoltaics (PVs), wind turbines, and hybrid configurations. To supply the results obtained with evidence, small-scale ORC performance at varied conditions is introduced based on extensive experimental results already 
published [1,2]. These works present a complete analysis of the performance of a two-stage, small-scale ( 10 kW) ORC operating at temperatures up to $140{ }^{\circ} \mathrm{C}$ that favors its application for geothermal small-scale microgrid integration. Scroll expenders have been used as expansion machines [3]. The latest developments in the subject in terms of technology evolution, market orientation, and social impact are thoroughly described next.

\subsection{Polygeneration Microgrids}

The autonomous polygeneration microgrid (APM) concept was first presented almost a decade ago [4]. It aims to holistically meet the needs of an off-grid community in terms of electrical loads, space heating and cooling, potable water production through desalination, and the use of hydrogen as fuel for transportation in the most cost-effective manner possible. At the same time, the use of renewables minimizes the carbon footprint of the community. In principle, any power source can be used in an APM. Photovoltaics (PVs) and wind turbines have been investigated extensively, since PVs can be installed practically anywhere in the world and wind turbines in areas with sufficient wind potential.

In addition to the initial research, advanced energy management systems were developed based on fuzzy logic [5], on a combined approach of petri nets and fuzzy cognitive maps [6], on a multi-agent system enabling demand-side management [7], and eventually an investigation of transitioning to a decentralized topology in the energy management system from the centralized one [8]. Other artificial intelligence paradigms were also investigated successfully, such as game theory [9] and fuzzy Q-learning [10]. The biggest improvement was observed when migrating from an on-off approach for the various subsystems to variable load operation. Investigation into the various components of the APM has also been realized. In [11] hybrid capacitors were investigated as an alternative to batteries, with higher utilization of the hydrogen subsystem with positive results. These results led to the realization of a hybrid capacitors bank [12]. Moreover, development and experimental analysis of a reverse osmosis desalination unit incorporating energy recovery also took place [13]. Nowadays commercial lithium ion batteries present high efficiencies, high depth of discharge, extended lifetimes, reasonable cost, and at the same time come with warranties of 10 years [14], which makes them prime candidates for use in polygeneration microgrids. A sustainability challenge is faced, especially in the developing world in relation to battery disposal and recycling [15].

\subsection{Geothermal ORC Power Generation}

Where available, low-enthalpy geothermal resources $\left(<150^{\circ} \mathrm{C}\right)$ can be a competent solution for electricity generation and are widespread around the world, occurring at shallow depths [16]; they could apparently play a key role in microgrid integration. At the same time, in many parts of the world, there are existing low-enthalpy geothermal wells that are used for a multitude of applications such as for buildings' heating and agriculture-related applications [17]. The low-temperature geothermal heat sources of concern can be exploited for electricity generation; however, this entails the appropriate heat-to-power conversion technology. To this end, the dominant technology to convert low-grade heat $\left(<150^{\circ} \mathrm{C}\right)$ to electricity is the Organic Rankine Cycle (ORC), as the current state of the art indicates. The main reason is that it exhibits higher conversion efficiency and maturity [18] compared to all alternative technical solutions (e.g., thermoelectric generator, Stirling engines, etc.). The thermal efficiency of the ORC is in the order of $5-6 \%$ when heat is supplied at $100{ }^{\circ} \mathrm{C}$, which is about $30 \%$ of Carnot efficiency $[19,20]$. Most of the ORC systems currently installed are in the range of a few hundred $\mathrm{kW}_{\mathrm{e}}$ to a few $\mathrm{MW}_{\mathrm{e}}$ [21]. In the field of geothermal electricity generation, an investigation into relevant literature reveals few systems that include autonomous geothermal electricity generation mostly in the $\mathrm{MW}_{\mathrm{e}}$ range [22,23], with few cases of geothermal-based isolated grids starting from $50 \mathrm{~kW}_{\mathrm{e}}$ [24,25]. Small ORC units have been researched and experimentally investigated. In Bologna, a $11 \mathrm{~kW}_{\mathrm{e}}$ capacity unit using R134a and a prototype four-cylinder piston expander was constructed and tested, exploiting a geothermal well with a temperature of $65^{\circ} \mathrm{C}$ with a net efficiency of $4.4 \%$ [26]. Another experimental ORC with a capacity of $1 \mathrm{~kW}_{\mathrm{e}}$ combined with a geothermal power plant of 85 to 
$105^{\circ} \mathrm{C}$ was developed in Germany, where two different working fluids, R245fa and R1233zd(E), were compared in terms of ORC efficient operation [27]. Moreover, a regenerative ORC-CHP plant with a twin-screw expander was developed, operating at a constant heat source temperature of $135^{\circ} \mathrm{C}$, resembling a geothermal source, and was tested in full and partial load operation, reaching a very high operational range and high efficiency in part-load operation [28]. Finally, three units with a capacity of a few $\mathrm{kW}_{\mathrm{e}}$ was developed, realized, and tested extensively at the Agricultural University of Athens $[2,19,29]$.

Concerns regarding the environmental sustainability of geothermal power plants are mainly concerned with $\mathrm{H}_{2} \mathrm{~S}$ and geothermal water release affecting water quality in the area [30]. As far as $\mathrm{H}_{2} \mathrm{~S}$ gas is concerned, the most common management approach is to include caustic scrubbing followed by oxidation, adsorption, and catalytic conversion in order to produce elemental sulfur [31]. This is very interesting especially for remote agricultural communities because elemental sulfur can be used as fertilizer [32]. As far as geothermal water is concerned, based on its chemical constitution, it can be utilized for irrigation after appropriate pre-treatment [33].

\subsection{ORC Market Trends}

The ORC market has experienced significant growth since the early 2000s, with an average yearly capacity between 75 and $200 \mathrm{MW}_{\mathrm{e}}$. In 2017, the ORC market was estimated to be between USD 359 million and 402 million per year, including the sales of equipment and direct engineering services [34]. In the early 2000s, small ORC units presented a much higher cost per $\mathrm{kW}_{\mathrm{e}}$, but units of less than $500 \mathrm{~kW}_{\mathrm{e}}$ did not represent more than $2 \%$ of the total installed capacity [34]. Recently, several low-temperature ORC engines have entered the market, decreasing the purchase cost while increasing the competition. ORC systems with an electric production lower than $20 \mathrm{~kW}_{\mathrm{e}}$ for use in residential or small industry applications have immerged, such as those of the French company Enogia, which trades in units of $10 \mathrm{~kW}_{\mathrm{e}}$ and $20 \mathrm{~kW}_{\mathrm{e}}$, suitable for heat source temperatures between $80^{\circ} \mathrm{C}$ and $120^{\circ} \mathrm{C}$ using R245fa and declaring a cycle efficiency range between $5 \%$ and $8 \%$, depending on the hot source and cold sink conditions [35]. In Italy, Zuccato company provides a unit of $30 \mathrm{~kW}_{\mathrm{e}}$, with a cycle efficiency of 8.5\% [36]. The company Infinity Turbine developed small ORC engines starting from $5 \mathrm{~kW}_{\mathrm{e}}$ [37], and Orcan Energy uses ORC in waste heat recovery with cycle power between $20 \mathrm{~kW}_{\mathrm{e}}$ and $100 \mathrm{~kW}_{\mathrm{e}}$ [38]. This growth of small-scale units and company competition has had an effect in reducing the relevant costs. In 2018, the global ORC market size was valued at USD 498.7 million, which is expected to grow at a compound annual growth rate of $9.7 \%$ over a forecast period up to 2025 [34]. The geothermal application segment has dominated the ORC market due to the large capacity of geothermal projects compared to other application segments such as biomass and waste heat recovery. There are, however, very few reports concerning the cost of a geothermal ORC application, with a rough estimation being USD $2000-3000 / \mathrm{kW}_{\mathrm{e}}$ installed [39]. Furthermore, ORC benefits such as the easy-to-install configuration, the equipment longevity, the potential use for co-generation applications, the environmental cost benefits, and the autonomous operation [40] make these systems attractive for application in microgrids.

\subsection{Merits of Geothermal Energy in Distributed Power Generation}

For different reasons, distributed geothermal power generation under a microgrid topology is of high value for both the developed and developing world. The renewable energy communities foreseen under the 2019 European Clean Energy Package [41] are expected to play a pivotal role in increasing distributed small-scale renewable power generation for their own use. This fact extends the field of possible application of APMs to urban and peri-urban areas of the EU. All around Europe, there are numerous low-enthalpy geothermal sources that can be utilized for small-scale on-site renewable energy production using ORC engines [42]. The possibilities of using existing geothermal wells, used until now only for heating purposes, can increase the co-generation of power and heat. This can find significant use especially in agriculture, since agriculture will also have to follow the targets set in the 
European Green Deal of Europe becoming the first climate-neutral continent. This in turn means it will also have to increase its renewable energy self-generation capacities. As a result, small-scale ORC units utilizing low-enthalpy geothermal sources can be viable investments not requiring excessive capital costs.

In 2019, there were still 860 million people without access to electricity, with most of them living in rural areas of Sub-Saharan Africa [43]. The East African Rift system has huge potential to provide electricity to the continent [44]. Many efforts have taken place to erect big geothermal energy power plants connected to the main grid in East Africa. The Geothermal Risk Mitigation Facility setup by the African Union Commission is one of the largest efforts to date to realize large-scale geothermal power plants [45]. At the same time, East African countries have just $42 \%$ of the population with access to electricity, which goes down to 31\% in rural areas [43]. Most of the remote rural areas of Sub-Saharan Africa are expected to get electricity through autonomous systems mainly in the form of microgrids [46]. In the developing world the application of small-scale ORC units in microgrids utilizing low-enthalpy geothermal energy resources can provide a low-cost alternative for providing energy access.

From the above analysis it can be clearly identified that geothermal power generation with ORC under a microgrid topology could play a key role in fulfilling in full basic power demand in small communities in both the developed and developing world. Nevertheless, the conditional framework that makes it technically and economically feasible should be determined by taking into consideration the competition from other, widely applied renewable energy sources (RES) technologies that dominate the microgrids sector, namely, PVs, wind turbines, or a combination of both at the same power scale.

\subsection{Scientific Contributions of the Paper}

The main contributions of this article can be summarized as: (1) After having developed and laboratory tested multiple low-temperature, low-power ORC engines, we used the testing results to develop a simulation model to investigate through simulations and optimizations its use in providing electricity and electricity-based services for off-grid locations through autonomous systems. (2) We compare techno-economically the use of the low-power ORC engines $\left(<15 \mathrm{~kW}_{\mathrm{e}}\right)$ with the most common approaches for providing electricity to autonomous systems that include PVs, wind turbines, and hybrid systems, highlighting the benefits of using an ORC engine where feasible. (3) Based on the results of the investigation we discuss possible use scenarios and possibilities for large-scale deployment of this technology for both the developed and developing world, also taking into consideration the environmental sustainability of these systems. For that purpose, a case study is elaborated for the representative case of a small settlement located on Milos island (Cyclades, Greece) using the APM concept [4], which aims at holistically meeting the needs of a remote area. Apart from the needs for transportation fuel, Milos island also faces potable water scarcity, making it necessary to include a desalination unit as a power load. Milos has high solar, wind, and geothermal potential, making it an ideal location for a comparative case study. An optimization platform consisting of TRNSYS 17, GenOpt 3, and TRNOPT was utilized. The optimization process was based on particle swarm optimization (PSO), which has been used with success in energy systems in general $[47,48]$ and APMs in particular $[4,6,9,11]$. The results show that the use of a small-scale low-temperature ORC engine use in an APM is technically feasible and more cost effective than PVs and wind turbines.

\section{Materials and Methods}

\subsection{Case Study Description}

The system was installed on Milos island in the Aegean Sea, Greece. Typical local meteorological data were utilized. The load consisted of 4 households occupied in total by 16 people. The heating and cooling needs of the buildings were met through the use of high-efficiency air-to-air heat pumps (Daikin FTXR28EV1B9) with nominal COP of 5.14. Each house had one freezer and one refrigerator. 
The Steca PF166 refrigerator/freezer was considered, with two appliances in each household: one operating in refrigerator mode and one in freezer mode [49]. The lighting needs of the households were met with the use of LED lamps. All electrical appliances considered were of high energy efficiency, and for cooking a typical electric grill and a typical induction cooker were considered. After the synthetic load was developed, variability was added from day to day and from timestep to timestep to make this synthetic profile more realistic [50]. The water needs of this small settlement were considered to be $3.84 \mathrm{~m}^{3} /$ day and this includes drinking water, laundry, sanitary, and bathing use. For the local transportation needs four hybrid hydrogen-battery scooters were assumed with a daily fuel consumption of $4.8 \mathrm{Nm}^{3} \mathrm{H}_{2}$. Since production and storage of hydrogen was considered, it was decided to also investigate the use of a fuel cell. Hydrogen has the benefit of being able to provide long-term energy storage and can complement a battery storage system [51].

Milos is blessed with high geothermal power potential. Many sources at multiple temperatures have been documented [52]. For the purposes of this case study it was assumed that the ORC unit was connected to one of the existing $95^{\circ} \mathrm{C}$ geothermal wells [52].

The prices of all system components were on par with commercial pricing in Greece. For the geothermal system a lump sum cost of EUR 15,000 was considered in line with the cost of the realized experimental units. The interest rate was assumed to be $6 \%$. The lifetime of all components was considered to be 20 years and 1 battery exchange was considered in this 20-year period, on par with the current 10-year warranties of high-quality lithium batteries. Annual maintenance was considered with a lump sum cost of EUR 500 for the PV and wind systems, which was based on commercial pricing in Greece. For the ORC engine system, an annual lump sum of EUR 750 was considered, due to the consumables required.

The available routines present in TRNSYS were used in combination with the routines presented in [6] for the hydrogen subsystem proton exchange membrane (PEM) electrolyzer, PEM fuel cell, and metal hydride storage tank), the desalination subsystem (reverse osmosis -RO-unit and water tank), and the rest of the microgrid components. The ORC engine was modeled based on the results obtained through the experimental investigation of the unit, and for the geothermal source assumed at $95^{\circ} \mathrm{C}$, an output of $3.35 \mathrm{~kW}_{\mathrm{e}}$ was considered [2]. The simulation timestep used was equal to $15 \mathrm{~min}$ and the simulations ran for a whole year.

In total 4 case studies were investigated. Since the ORC unit that was been developed could form a grid, batteries and a grid-forming inverter were considered for all case studies. The configuration of each case study is presented in Table 1. Case Studies 1, 2, and 3 are essentially the currently investigated solutions, comprising PVs and wind turbines. Case Study 4 is where the geothermal ORC engine was investigated.

Table 1. Autonomous Polygeneration Microgrid (APM) configurations.

\begin{tabular}{cccc}
\hline Case Study No. & PVs & Wind Turbines & Geothermal ORC \\
\hline 1 & $\mathrm{X}$ & $\mathrm{X}$ & \\
2 & & $\mathrm{X}$ & \\
3 & $\mathrm{X}$ & & $\mathrm{X}$ \\
4 & & & \\
\hline
\end{tabular}

\subsection{Microgrid Configuration}

Based on the case study described in the previous section the designed APM is presented in Figure 1. Depending on the configuration investigated some of the power generation components may not have been used in that particular configuration. The components were:

- PV array: A typical monocrystalline silicon PV array was considered.

- Wind turbine: A typical $7.5 \mathrm{~kW}$ direct current (DC) wind turbine was considered. 
- Desalination unit: A custom reverse osmosis (RO) desalination unit equipped with hydraulic energy recovery was considered. One such unit was experimentally tested at the Agricultural University of Athens [13].

- Fuel cell: A typical proton exchange membrane (PEM) fuel cell was used [6].

- Electrolyzer: A typical PEM electrolyzer supplying hydrogen at high pressure ( 15 bar) was considered [6].

- Low-pressure (<30 bar) hydrogen storage tank: A typical tank was used.

- Hydrogen vehicles: Hybrid fuel cell battery scooters were considered. These were assumed to have a fuel consumption of $2.4 \mathrm{Nm}^{3}$ of $\mathrm{H}_{2} / 100 \mathrm{~km} \mathrm{[6].}$

- Power inverters: Typical commercially available microgrid inverters were considered [6].

- ORC engine: The unit presented in [2] was considered. This unit produces $3.35 \mathrm{~kW}_{\mathrm{e}}$ when fed with a temperature of $95^{\circ} \mathrm{C}$.

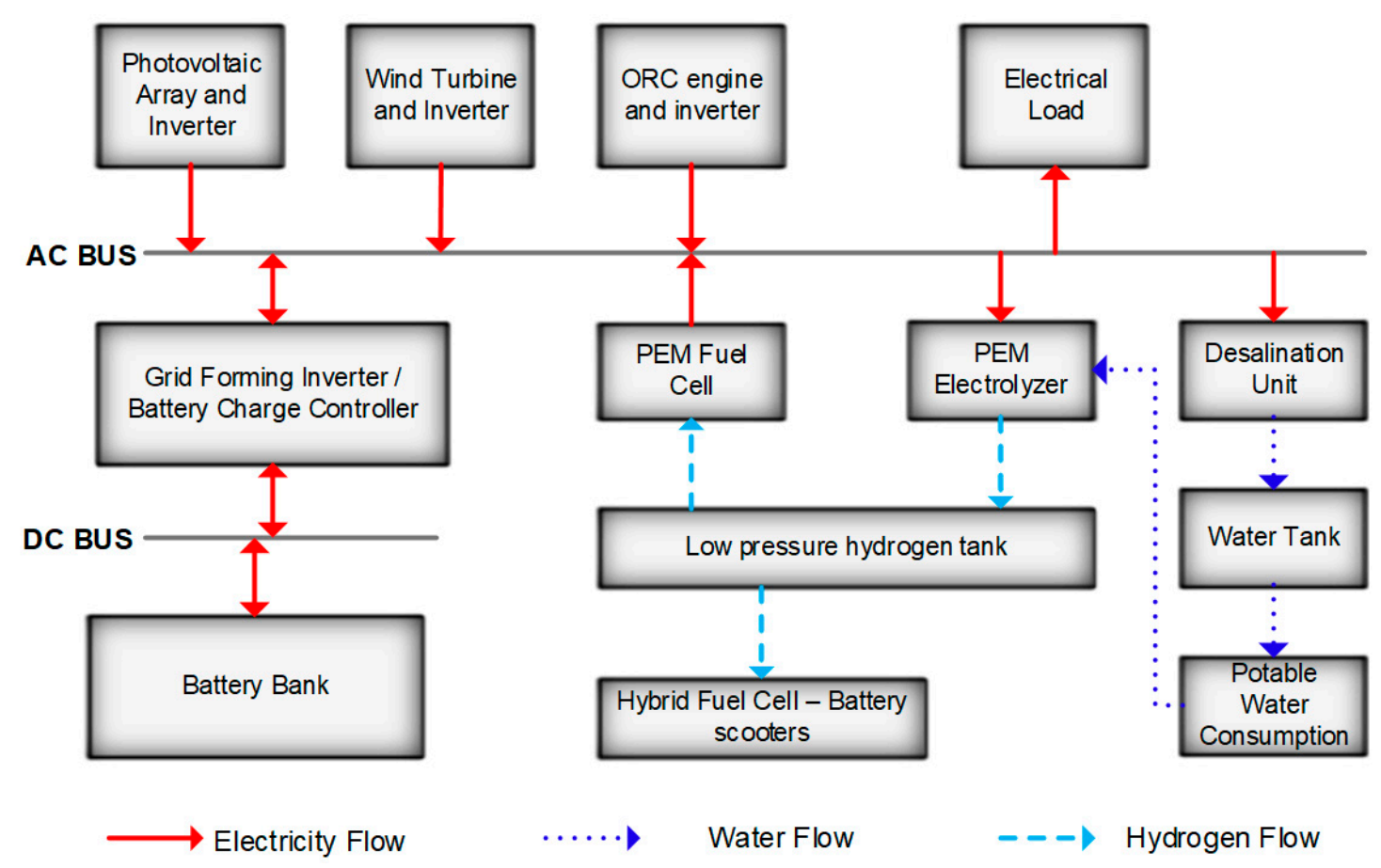

Figure 1. Schematic presentation of the autonomous polygeneration microgrid.

\subsection{Energy Management System}

The APM topology is a complex one requiring an advanced energy management system (EMS) in order to operate. As discussed in the Introduction, different approaches have been developed and utilized effectively. In this paper it was decided to use the combined approach of Petri nets (PN) and fuzzy cognitive maps (FCM), which was presented in [6]. This EMS is able to effectively utilize systems comprising PVs, wind turbines, and external power sources as well as the always-activated geothermal ORC unit investigated in this paper.

\section{Optimization Approach}

For each configuration of the APM there were two sets of variables that needed to be optimized. The first concerned the sizing of each of the system components, e.g., the number of PV panels, number of batteries, rated power of the desalination plant, etc. The second set concerned the actual parameters in the energy management system. Since the optimal set of parameters was directly correlated with the sizing of the various subsystems of the APM, it was decided that the optimization of both sets would take place at the same time. 
The software platform used, consisting of TRNSYS, GenOPT, and TRNOPT, allows for the simultaneous optimization of 100 parameters and a combination of discrete and continuous variables. The number of PV panels is an example of a discrete variable and the value of the FCM weights is an example of a continuous variable.

PSO was used for the optimization. The parameters of the PSO utilized are presented in Table 2 and are a set that has been utilized extensively with success for APMs $[6,7,9,11]$.

Table 2. PSO parameters.

\begin{tabular}{cc}
\hline Topology & Lbest \\
\hline Neighborhood size & 3 \\
Particles & 20 \\
Generations & 100 \\
Seed & 0 \\
Constriction gain & 0.729 \\
Cognitive acceleration constant & 2.05 \\
Social acceleration constant & 2.05 \\
\hline
\end{tabular}

The optimization was techno-economic. The designed systems needed to meet the needs in electricity, potable water, and transportation fuel at 100\% throughout the year. As such the optimization process aimed to design the system with the lowest net present cost (NPC) while at the same time fulfilling all technical constraints. The technical constraints set were:

- The lithium ion batteries are not discharged more than a state of charge (SOC) equal to $5 \%$.

- There is no water shortage. This in turn means that the potable water tank never gets empty.

- There is no hydrogen fuel shortage. This in turn means that the hydrogen metal hydride tank never gets empty.

- The stored potable water in the water tank and the stored hydrogen in the hydrogen metal hydride tank at the end of the year have equal or larger quantities stored in comparison with the beginning of the year.

The technical constraints were monetized using a simple process. When all the technical constraints were met for all timesteps of the yearly simulation then the penalty related to them was zero. For each timestep for which a single technical constraint was not met, a monetary penalty of EUR 1,000,000 was added to the net present cost. The optimization cost function (CF) was thus formed as follows:

$$
\mathrm{CF}=\mathrm{NPC}+\sum_{t=1}^{8760} \mathrm{P}_{\mathrm{b}}(t)+\sum_{t=1}^{8760} \mathrm{P}_{\mathrm{H}_{2}}(t)+\sum_{t=1}^{8760} \mathrm{P}_{\mathrm{W}}(t)+\mathrm{P}_{\mathrm{S}}
$$

where:

NPC: net present cost for a 20-year period;

$\mathrm{P}_{\mathrm{b}}$ : battery penalty;

$\mathrm{P}_{\mathrm{H} 2}$ : hydrogen penalty;

$\mathrm{P}_{\mathrm{w}}$ : water penalty; and

$P_{\mathrm{S}}$ : tanks penalty.

The above equation was modeled in TRNSYS with new subroutines written in order to realize the specific penalties (battery, hydrogen, water, and tanks). GenOPT was used for implementing the particle swarm optimization process. GenOPT is written in Java and the code is available. The GenOPT software is provided under a modified BSD license [53].

\section{Case Study Results}

The optimization boundaries for each variable for each of the case studies and the corresponding results are presented in Tables 3-6. The boundaries of the search space for each case study were decided 
based on the experience gained upon making a number of test simulations for each configuration. Especially for the system in Case Study No. 4, it was assumed that two ORC engines were installed with a total power of $6.70 \mathrm{~kW}$; test simulations showed that a system with one engine was unable to meet the set load. Table 7 presents the NPC of each of the four case studies, along with key data for each optimized system. The variables SOCL and SOCM are related to the Petri net and the weights $\left(\mathrm{W}_{\mathrm{n}}\right)$ are related to the fuzzy cognitive map as analyzed in [6].

The results of the first three case studies were in line with expectations for such a system. The cost of PVs has been decreasing considerably throughout the past decade and as such it makes sense to have larger PV arrays powering loads that can be scheduled during the day, storing as little energy in the battery bank as possible. For Case Study No. 1, which had only PVs installed, the optimization provided a system with a very large PV array and the minimum feasible battery bank. This means that the electrolyzer and desalination units operated mostly during daylight hours. While it was assumed that enough land space was available to install any size of PV array in this study, it has to be noted that many times, especially in the developed world, land comes at a cost or simply might not be available. A $45 \mathrm{kWp}$ PV array utilized in Case Study No. 1 would roughly need $1350 \mathrm{~m}^{2}$. A fuel cell was utilized as a backup power source.

Milos has high wind potential. Due to the intermittent character of wind, a large battery bank coupled with large hydrogen and potable water tanks is needed to ensure that the loads are met throughout the year. As such, it presents a higher NPC in comparison with the PV-only system in Case Study No.1. This system also utilized a fuel cell as a backup power source.

Table 3. Case Study No. 1-PVs only.

\begin{tabular}{|c|c|c|c|c|}
\hline Variable & Lowest Value & Highest Value & Step & Optimal Value \\
\hline \multicolumn{5}{|c|}{ System Components } \\
\hline $2.56 \mathrm{kWh} 48 \mathrm{~V} \mathrm{LiFePO}_{4}$ batteries & 1 & 20 & 1 & 10 \\
\hline Typical modules rated at $180 \mathrm{Wp}$ each & 250 & 320 & 2 & 250 \\
\hline Rated power of the fuel cell (W) & 0 & 1500 & 100 & 600 \\
\hline Rated power of the electrolyzer unit (W) & 500 & 3000 & 100 & 2500 \\
\hline $\begin{array}{l}\text { Low-pressure hydrogen tank storage } \\
\text { capacity }\left(\mathrm{Nm}^{3} \text { of } \mathrm{H}_{2}\right)\end{array}$ & 2.5 & 40 & 2.5 & 35 \\
\hline Desalinated water tank volume $\left(\mathrm{m}^{3}\right)$ & 5 & 50 & 5 & 45 \\
\hline Rated power of the desalination unit (W) & 1200 & 2500 & 100 & 2200 \\
\hline \multicolumn{5}{|c|}{ Energy Management System Variables } \\
\hline SOCL & 20 & 32 & 1 & 29 \\
\hline SOCM & 43 & 67 & 1 & 43 \\
\hline W13 & -1 & 0 & Continuous & -0.52 \\
\hline W14 & -1 & 0 & Continuous & -0.94 \\
\hline W15 & 0 & 1 & Continuous & 0.62 \\
\hline W23 & 0 & 1 & Continuous & 0.30 \\
\hline W24 & 0 & 1 & Continuous & 0.77 \\
\hline W25 & 0 & 1 & Continuous & 0.38 \\
\hline
\end{tabular}


Table 4. Case Study No. 2-wind turbines only.

\begin{tabular}{ccccc}
\hline Variable & Lowest Value & Highest Value & Step & Optimal Value \\
\hline & System Components & & \\
\hline 2.56 kWh 48V LiFePO 4 batteries & 1 & 40 & 1 & 25 \\
\hline Typical 7.5 DC wind turbine & 3 & 9 & 1 & 5 \\
\hline Rated power of the fuel cell $(\mathrm{W})$ & 0 & 2000 & 100 & 200 \\
\hline Rated power of the electrolyzer unit $(\mathrm{W})$ & 500 & 3000 & 250 & 3000 \\
\hline $\begin{array}{c}\text { Low-pressure hydrogen tank storage } \\
\left.\text { capacity (Nm }{ }^{3} \text { of } \mathrm{H}_{2}\right)\end{array}$ & 2.5 & 40 & 2.5 & 32.5 \\
\hline Desalinated water tank volume $\left(\mathrm{m}^{3}\right)$ & 5 & 50 & 5 & 50 \\
\hline Rated power of the desalination unit $(\mathrm{W})$ & 800 & 2500 & 100 & 1500 \\
\hline Energy Management System Variables & 32 & 1 & 30 \\
\hline SOCL & 20 & 67 & 1 & 67 \\
\hline SOCM & 43 & 0 & Continuous & -0.90 \\
\hline W13 & -1 & 0 & Continuous & -0.99 \\
\hline W14 & -1 & 1 & Continuous & 0.07 \\
\hline W15 & 0 & 1 & Continuous & 0.26 \\
\hline W23 & 0 & 1 & Continuous & 0.93 \\
\hline W24 & 0 & 1 & Continuous & 0.13 \\
\hline W25 & 0 & &
\end{tabular}

Table 5. Case Study No. 3-PV and wind turbine hybrid.

\begin{tabular}{ccccc}
\hline Variable & Lowest Value & Highest Value & Step & Optimal Value \\
\hline & System Components & & \\
\hline 2.56 kWh 48V LiFePO 4 batteries & 1 & 25 & 1 & 4 \\
\hline Typical modules rated at $180 \mathrm{Wp}$ each & 10 & 150 & 2 & 150 \\
\hline Typical 7.5 DC wind turbine & 1 & 4 & 1 & 2 \\
\hline Rated power of the fuel cell $(\mathrm{W})$ & 0 & 2000 & 100 & 0 \\
\hline Rated power of the electrolyzer unit $(\mathrm{W})$ & 500 & 3000 & 100 & 1900 \\
\hline $\begin{array}{c}\text { Low-pressure hydrogen tank storage } \\
\left.\text { capacity (Nm }{ }^{3} \text { of } \mathrm{H}_{2}\right)\end{array}$ & 2.5 & 40 & 2.5 & 12.5 \\
\hline Desalinated water tank volume $\left(\mathrm{m}^{3}\right)$ & 5 & 50 & 5 & 10 \\
\hline Rated power of the desalination unit $(\mathrm{W})$ & 800 & 2500 & 100 & 1600 \\
\hline Energy Management System Variables & & 1 & 29 \\
\hline SOCL & 20 & 32 & 1 & 43 \\
\hline SOCM & 43 & 67 & & -0.66 \\
\hline W13 & -1 & 0 & Continuous & -0.08 \\
\hline W14 & -1 & 0 & Continuous & 0.68 \\
\hline W15 & 0 & 1 & Continuous & 0.66 \\
\hline W23 & 0 & 1 & Continuous & 0.53 \\
\hline W24 & 0 & 1 & Continuous & 0.62 \\
\hline W25 & 0 & 1 & Continuous & \\
\hline
\end{tabular}


Table 6. Case Study No. 4-Geothermal ORC.

\begin{tabular}{ccccc}
\hline Variable & Lowest Value & Highest Value & Step & Optimal Value \\
\hline & System Components & & \\
\hline 2.56 kWh 48 $\mathrm{LiFePO}_{4}$ batteries & 1 & 5 & 1 & 1 \\
\hline Rated power of the electrolyzer unit $(\mathrm{W})$ & 500 & 1800 & 250 & 1000 \\
\hline $\begin{array}{c}\text { Low-pressure hydrogen tank storage } \\
\text { capacity }\left(\mathrm{Nm}^{3} \text { of } \mathrm{H}_{2}\right)\end{array}$ & 2.5 & 7.5 & 2.5 & 5 \\
\hline $\begin{array}{c}\text { Rated power of the desalination unit }(\mathrm{W}) \\
\text { Energy Management System Variables }\end{array}$ & 800 & 32 & 100 & 1100 \\
\hline $\mathrm{SOCL}$ & 20 & 67 & 1 & 23 \\
\hline $\mathrm{SOCM}$ & 43 & 0 & Continuous & -0.04 \\
\hline $\mathrm{W} 13$ & -1 & 0 & Continuous & -0.20 \\
\hline $\mathrm{W} 14$ & -1 & 1 & Continuous & 0.61 \\
\hline $\mathrm{W} 15$ & 0 & 1 & Continuous & 0.44 \\
\hline $\mathrm{W} 23$ & 0 & 1 & Continuous & 0.30 \\
\hline $\mathrm{W} 24$ & 0 & 1 & Continuous & 0.60 \\
\hline $\mathrm{W} 25$ & 0 & &
\end{tabular}

Table 7. Comparative presentation of the case studies' optimization results.

\begin{tabular}{ccccc}
\hline & $\begin{array}{c}\text { No. 1 } \\
\text { PVs Only }\end{array}$ & $\begin{array}{c}\text { No. 2 Wind } \\
\text { Turbines Only }\end{array}$ & $\begin{array}{c}\text { No. 3 PV and Wind } \\
\text { Turbine Hybrid }\end{array}$ & $\begin{array}{c}\text { No. 4 Geothermal } \\
\text { ORC Only }\end{array}$ \\
\hline Net Present Cost $(\mathrm{NPC})(\mathrm{EUR})$ & 168,052 & 207,852 & 125,602 & 73,202 \\
\hline PV $(\mathrm{kWp})$ & 45.00 & - & 27.00 & - \\
\hline Wind turbines $(\mathrm{kW})$ & - & 37.50 & 15.00 & - \\
\hline ORC engines $(\mathrm{kW})$ & - & - & - & 6.70 \\
\hline Batteries $(\mathrm{kWh})$ & 25.60 & 64.00 & 10.24 & 2.54 \\
\hline Electrolyzer $(\mathrm{kW})$ & 2.50 & 3.00 & 1.90 & 1.00 \\
\hline Hydrogen storage tank $\left(\mathrm{Nm}^{3} \mathrm{H}_{2}\right)$ & 35 & 32.50 & 12.50 & 5.00 \\
\hline Fuel cell $(\mathrm{kW})$ & 0.60 & 0.20 & - & - \\
\hline Desalination unit $(\mathrm{kW})$ & 2.20 & 1.50 & 1.60 & 1.10 \\
\hline Potable water tank $\left(\mathrm{m}^{3}\right)$ & 45 & 50 & 10 & 5 \\
\hline
\end{tabular}

The hybrid system of Case Study No. 3 performed better, as expected, with a lower NPC in comparison with PV-only or wind turbine-only systems, since statistically there is a chance that wind power is available when solar is not and vice versa, leading also to decreased need for battery bank energy storage as well as hydrogen and water tanks. In a location where a geothermal source was not available, the hybrid system would have been selected if there had been sufficient wind potential, or the PV-only system in any other location. Due to the hybridization of energy generation, a fuel cell was not needed under this configuration.

The ORC engine-based APM outperformed the other configurations by a large margin. The hybrid $\mathrm{APM}$, which was the next best solution, presented a $72 \%$ higher NPC. The constant power production by the ORC engines minimized the need for a large battery bank or hydrogen and water tanks. The battery and tanks utilized were essentially used as short-term buffers. As far as the optimization of the EMS variables is concerned, it is clearly presented that different parameters provided better results for the size of the specific components in each configuration.

Optimizing the EMS at the same time as sizing the various subsystems ensures optimal and cost-effective system design. As is observed from the results, a different set of the EMS parameters was chosen for each of the configurations to provide optimal operation.

The main use of the hydrogen subsystem was to provide fuel for transportation. At the same time, though, the inclusion of a fuel cell was investigated for the case studies that included intermittent power sources. The cost of a fuel cell is still high and it has to compete with the decreasing cost of 
lithium batteries. As such in Case Studies 1 and 2, a low-power fuel cell was used as an emergency backup system. In the hybrid system, a fuel cell backup was not needed at all. Figure 2 presents the stored hydrogen throughout the year in the hydrogen tank for all four configurations of the APM. As can be seen, the ORC system (Case Study No. 4) used the tank the same way throughout the year, since power generation was steady and constant, essentially having only a daily variation. For the other three systems, depending on the output of the PVs and wind turbines, the tanks were used for longer-term storage, as is visible in the spikes when the tanks got near to empty, while the daily variation was comparable to the ORC engine system. The size of the tank in each system ensured that hydrogen demand was met throughout the year and that the hydrogen stored at the end of the year was equal to or higher than the quantity stored at the beginning of the year.

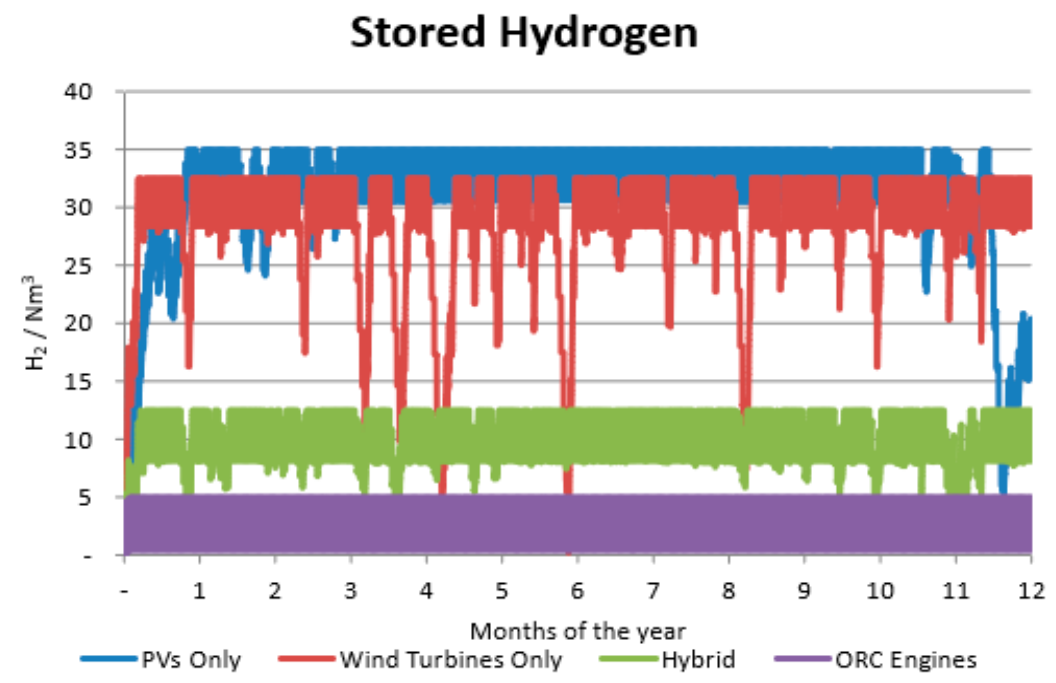

Figure 2. Stored hydrogen throughout the year.

The seawater desalination sub-system presents the option for longer-term energy storage in the form of desalinated water. The first two case studies sized the water tank at or near the maximum considered size, essentially using a tank able to meet the water load for over 10 days as presented in Figure 3. A tank larger than $50 \mathrm{~m}^{3}$ was not considered in the optimization process due to logistic issues involved in transporting such a tank to a remote location. In the PV-only and wind turbine APMs, the water tank was used for longer-term storage. The hybrid system managed to operate effectively using a much smaller water tank. Finally, the ORC engine-based system was able to operate effectively with a lower rated desalination unit and an even smaller potable water tank due to the constant power production.

For each configuration, typical days are presented. For the first three cases, a good day (surplus power generation), an average day (average power generation), and a bad day (low power generation) were chosen. For the ORC case study, only one day is presented, since power generation was constant throughout the year. These days were different for each system, since effort was made to choose days that highlighted the operation of each configuration more effectively. Since different intermittent sources were used in each configuration, the use of the same days for all systems would not succeed in highlighting the specific operational characteristics of each configuration. Figure 4 presents Case Study No. 1, which was equipped only with PVs. The first day chosen was 17 May and, as is visible, the power output from the PVs was high throughout the daylight hours of the day. Since there was a surplus of power, both the electrolyzer and the desalination unit were operated to produce the needed water and hydrogen. This was preferred to running these devices during the night, since battery use has a higher overall cost and lower efficiency than using the power as it is produced from the PV array. 


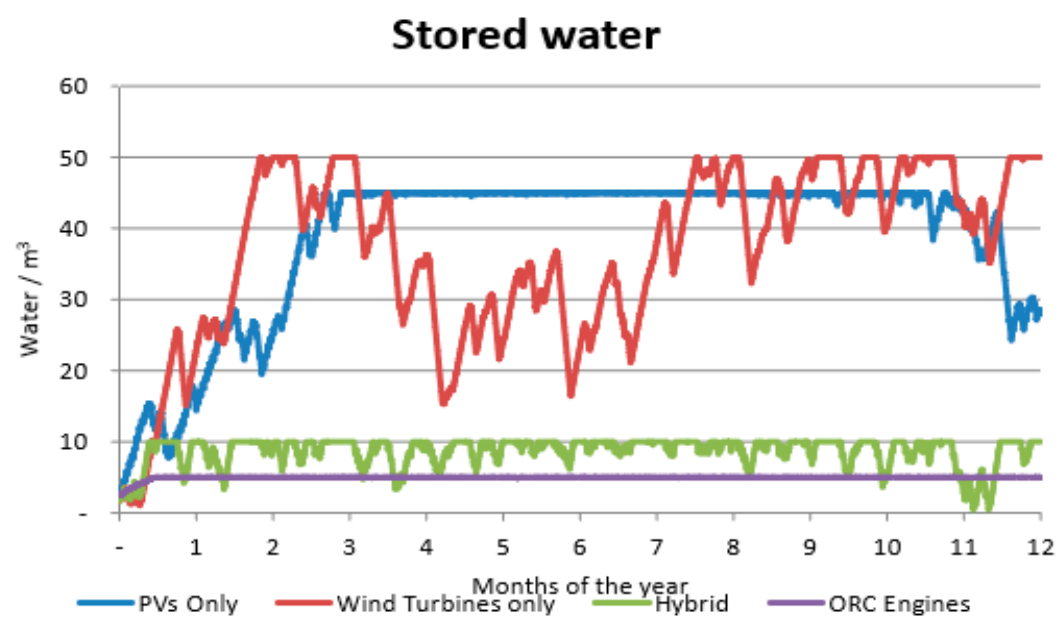

Figure 3. Stored water throughout the year.

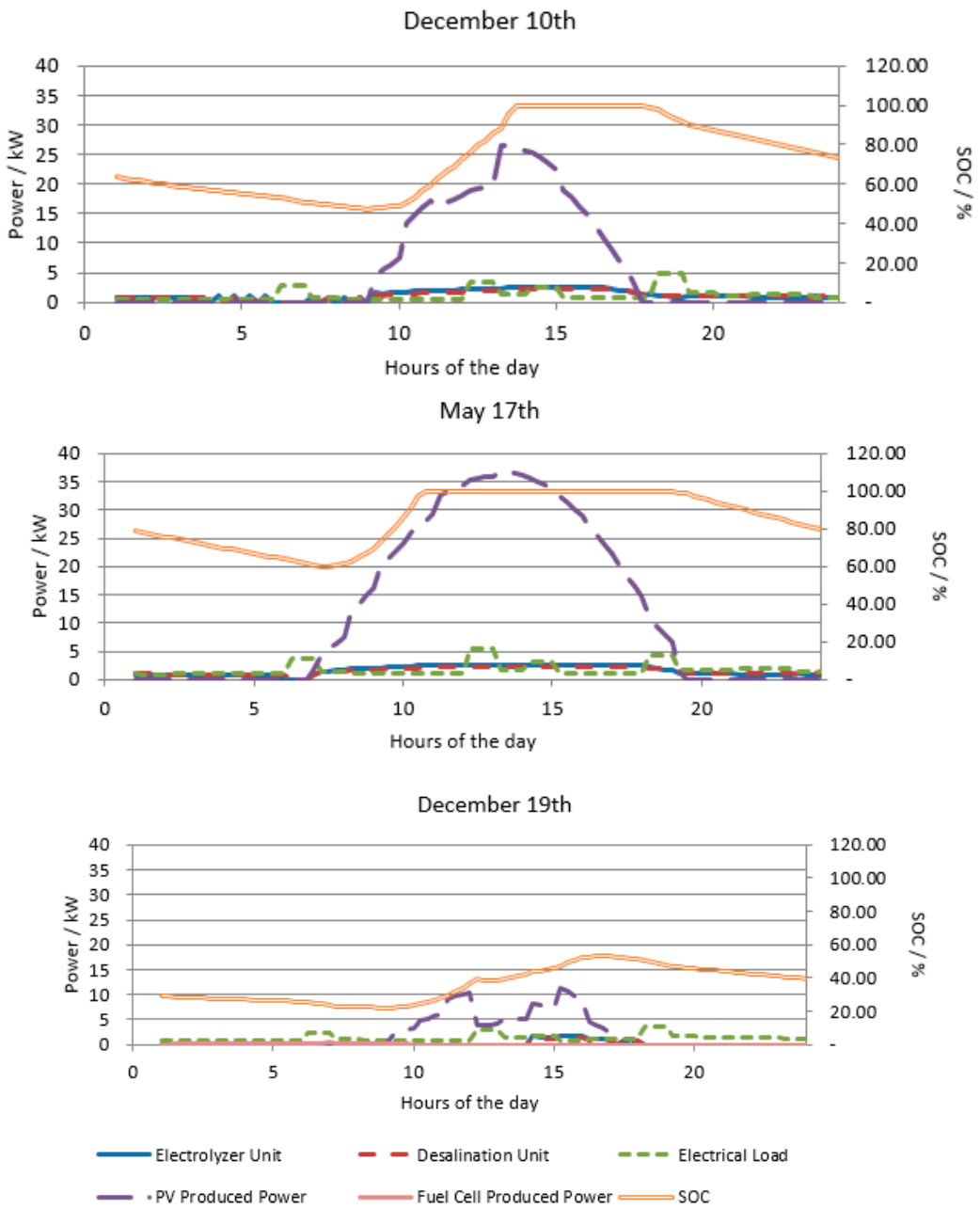

Figure 4. Case Study No. 1-PV-only APM characteristic days.

The second day was 10 December. During this day there was some power production from the PV array. The SOC of the battery started the day at around $80 \%$ then decreased to $60 \%$ as the battery supplied the needed power. Then as the PV array started to produce power, the SOC increased again until the battery bank was fully charged. The third day was 19 December. The SOC was around 30\% at midnight and decreased further. The EMS activated the fuel cell at 01:30 a.m. to decrease the rate of 
discharge and was deactivated when the PVs started to produce power. The PV produced power was very low this day, but still enough to charge the battery bank. The EMS activated the electrolyzer and desalination unit in partial load, still allowing the SOC of the battery bank to increase. When the sun set the electrolyzer and desalination unit were deactivated.

Figure 5 presents three days for Case Study No. 2, which was equipped only with wind turbines. The first day was 2 February. During this day the wind potential was very high and the wind turbines operated near their maximum power output point from early in the morning until late at night. Both the electrolyzer and desalination units were activated and the battery bank remained practically full throughout the day. The second day chosen for this system was 28 June. During this day there was practically no power production from the wind turbines from midnight until about 11:00 a.m., and the battery SOC was very low. As such the EMS activated the fuel cell as an emergency power source to act as an emergency backup system. Due to this the system managed to continue meeting the load. As the produced power increased the SOC increased as well and in the evening both the electrolyzer and desalination units were activated.

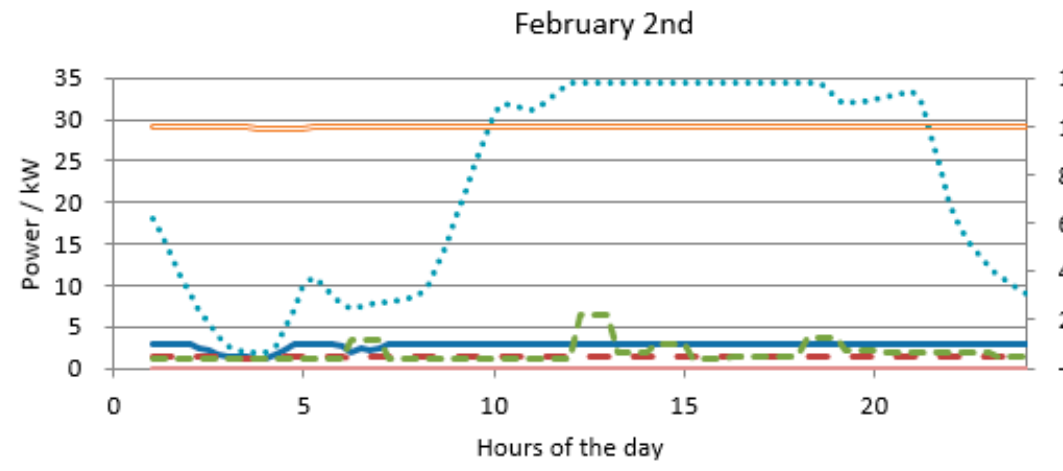

120.00 100.00 80.00 60.00 40.00 20.00

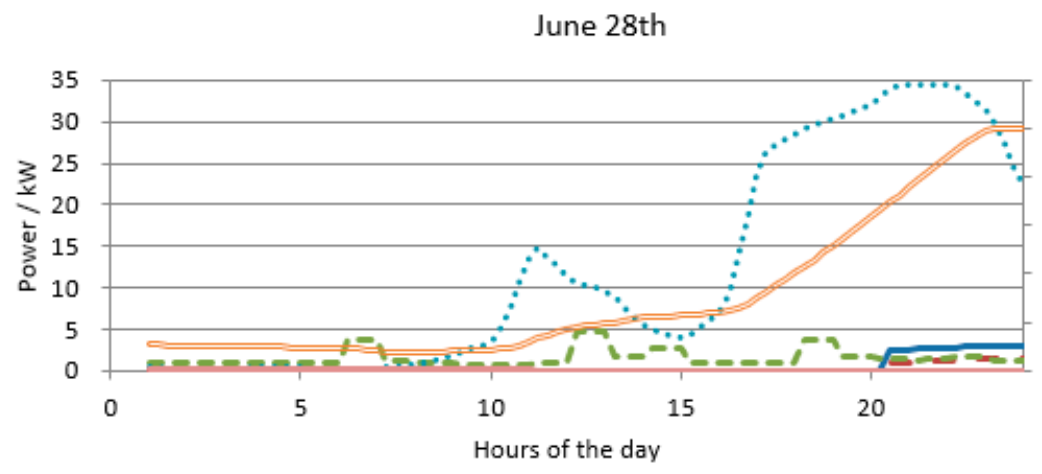
120.00 100.00 80.00 60.00 40.00 20.00

October 31st
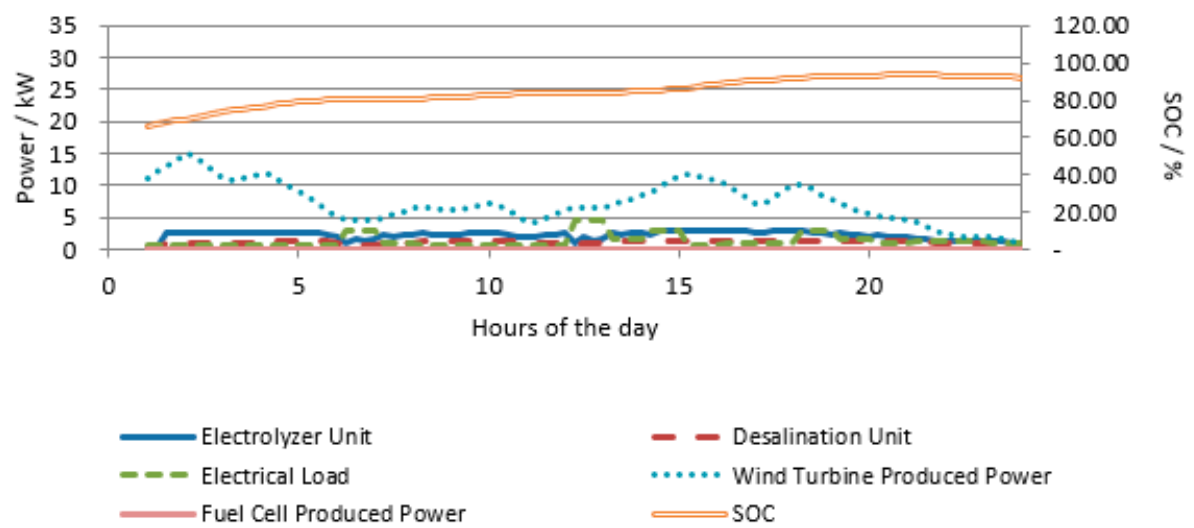

Figure 5. Case Study No. 2-wind turbine-only APM characteristic days. 
The final day was 31 October. While the production from the wind turbines was not high in relation to their rated power, there was constant production, which was able to meet the load. The desalination and electrolyzer units operated throughout the day in variable operation points.

The hybrid system aimed to couple two intermittent sources based on the fact that solar and wind potential have a different profile in time. The first day presented in Figure 6 was 12 March. During this day the wind turbines did not produce any power and the weather was cloudy, leading to non-optimal PV power production. Still, the PV array was large enough to produce enough power to charge the battery bank and allow both the desalination and electrolyzer units to operate throughout the day and until late in the evening. When the SOC started to decrease again the EMS deactivated the electrolyzer and decreased the point of operation of the desalination unit. During the late hours of the day, the wind turbines started to produce power again and the discharge rate of the battery bank was decreased. The second day chosen was 17 May, which was a really good day since both solar and wind potential were high. The battery bank remained practically full throughout the day and both the electrolyzer and desalination units were activated at full load. The last day was 1 October. The PV production throughout the day was good, but the power output of the wind turbines was low and only for a few hours in the day. The battery bank was discharged until sunrise, meeting the electrical load of the households with the desalination and electrolyzer units deactivated. As the SOC increased due to the PV-produced power, the desalination and electrolyzer units were also activated, initially at full load and then at partial load as the sun started to set.

The ORC engine-based system did not present an intermittent power output. The variability in the operation of this system was only related to load variability between days. The system was equipped with only one battery ( $48 \mathrm{~V} / 2.56 \mathrm{kWh})$. The date 7 June is presented in Figure 7 . As can be seen, the electrolyzer and desalination unit were activated throughout the day. As the load of the households changed, the EMS changed the point of operation of the desalination and electrolyzer units in order to not discharge the battery bank considerably. Due to this fact, lower power rating electrolyzer and desalination units could be utilized, which have a significant effect on decreasing the capital cost of the system.

Finally, in Figure 8 the annually produced energy of each configuration is presented. As is clear, while all systems met the same needs, there were great differences in the produced energy throughout the year. This is the result of mainly two factors. The first factor is that for the systems based on intermittent renewables, the generation and demand did not taking place at the same time. There are two main options to address this situation: The first is to use energy storage and the second is to increase the installed power of the system. The most common approach is to use techno-economic optimization, since at the end of the day, the load needs to be met at the minimum possible cost, as was also followed in this paper. Consequently, the balance between generation and storage has to do with the pricing of the various components installed. This is why the hybrid system presented lower NPC than the PV-only system, even though it had to produce more energy to meet the load. As is understandable, the excess energy is wasted because it does not make sense cost-wise to store it. The constant output of the ORC engines essentially waives the need for energy storage beyond buffers that ensure optimal operation. It has to be kept in mind that one of the technical constraints of the optimizations is that the load is met at all times throughout the year, which essentially simulates grid-like performance. 
March 12th

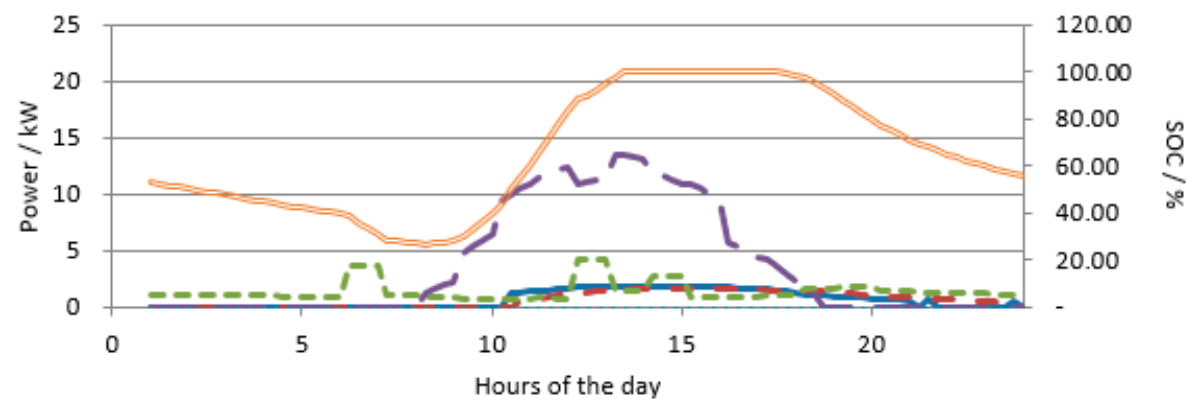

May 17th

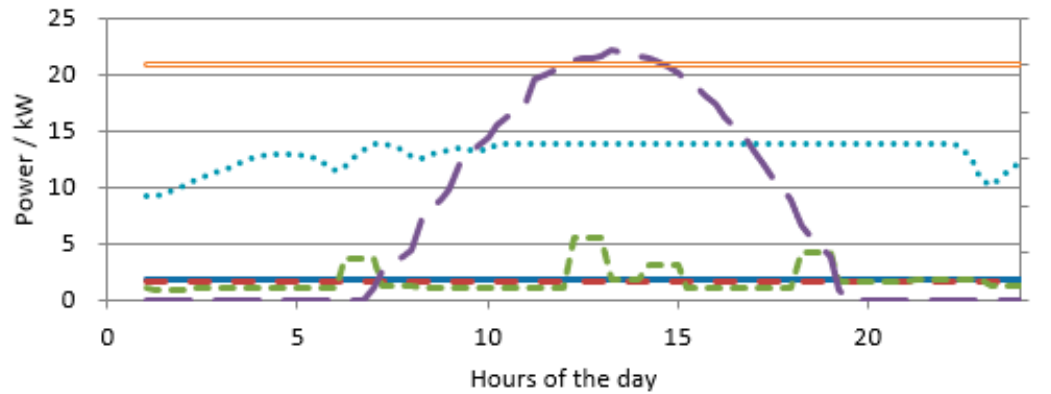

120.00

100.00

80.00

60.00

40.00

20.00

October 1st
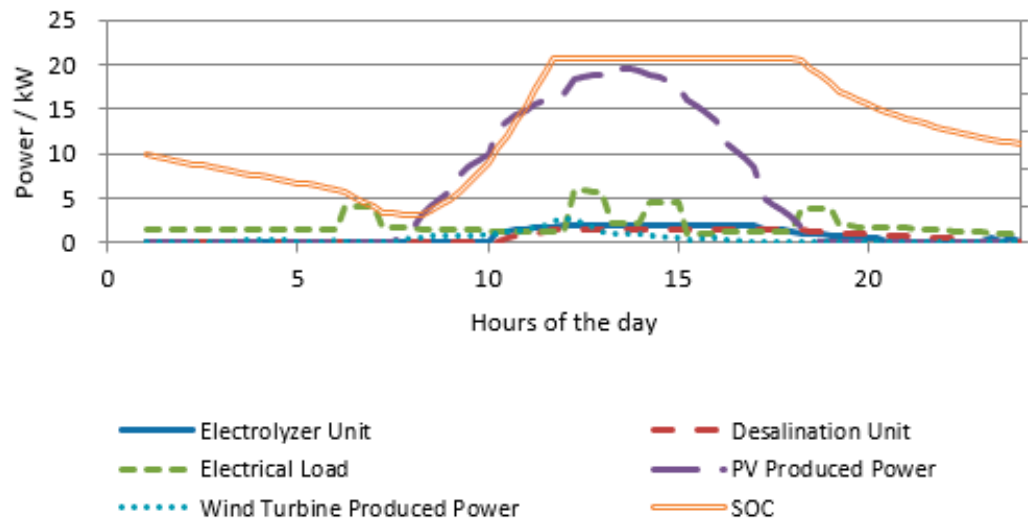

...... Wind Turbine Produced Power

20.00

Figure 6. Case Study No. 3-hybrid APM characteristic days.

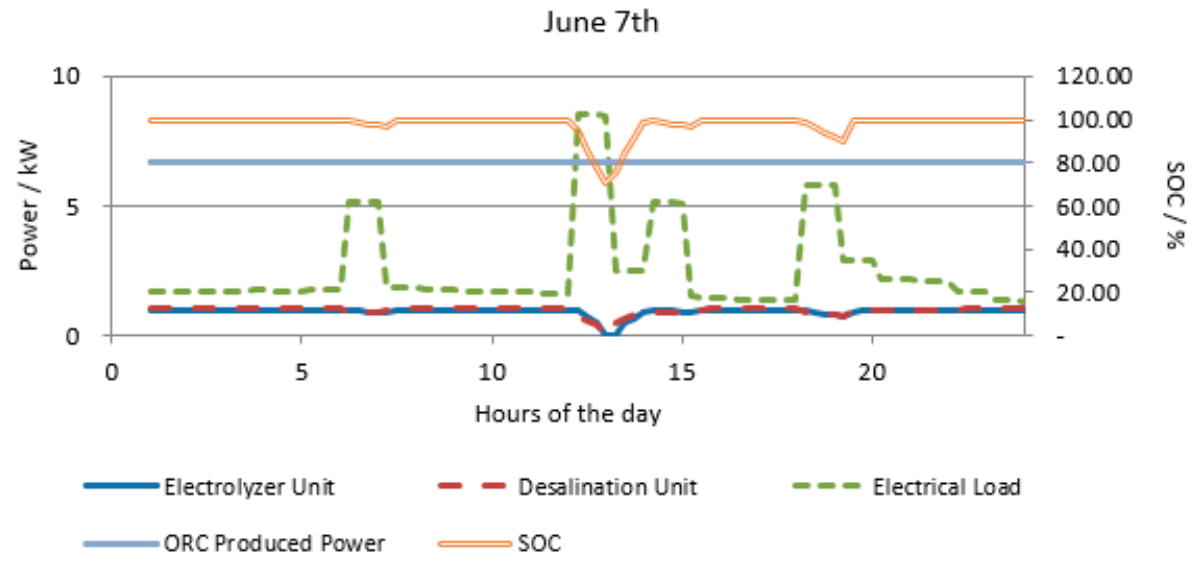

Figure 7. Case Study No. 4-ORC engine APM characteristic day. 
Annually produced energy (MWh)

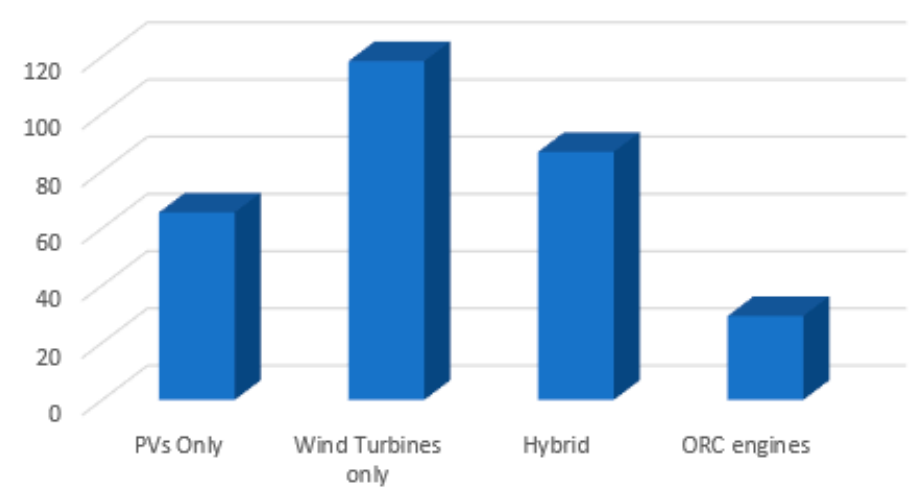

Figure 8. Annually produced energy.

\section{Discussion}

The APM topology was developed aiming to meet the needs in a remote area in a holistic and sustainable manner with applications both in the developed and the developing world. In principle any power source can be used in this topology, but the most commonly used ones are PVs followed by wind turbines, since other power sources such as geothermal energy are not available everywhere. Moreover, it has been only in recent years that ORC engines with low power ratings $\left(<10 \mathrm{~kW}_{\mathrm{e}}\right)$ able to use low-temperature intake $\left(<100^{\circ} \mathrm{C}\right)$ have been introduced to the market. It has to be highlighted that the power output of the ORC engines is dependent on the temperature of the heat source. The unit utilized in this study produces $3.35 \mathrm{~kW}_{\mathrm{e}}$ at $95^{\circ} \mathrm{C}$, which almost doubles at $6.83 \mathrm{~kW}_{\mathrm{e}}$ at $120^{\circ} \mathrm{C}$ [2]. This means that for a $120^{\circ} \mathrm{C}$ geothermal source, a second engine would not be needed, further decreasing the cost. At the same time research for geothermal sources has been taking place globally for decades. Many geothermal wells opened for testing purposes remain unused due to many reasons, some of which include lower temperatures and geothermal potential than initially anticipated, a better source being found in the greater area of exploration, or use for only heating applications. Any existing low-enthalpy geothermal well can be potentially used for low-power applications such as the one proposed in this paper. While one of the assumptions of this paper is the presence of a geothermal well, the results leave sufficient room for including well-related costs and the investment is still more cost-effective than the alternatives.

As was clearly shown in the results of this paper, a system based on an ORC engine minimizes battery bank size, which in turn minimizes the operation and maintenance costs of microgrids, which can ultimately also increase the real operational life of these systems. On the matter of resilience of these systems in the case of a component failure, all configurations investigated perform comparably, since most of the hardware is the same. The major challenge faced in such microgrids is the remoteness and how easy it is to access the location. In any case, the employment of an intelligent demand-side management system such as the one presented in [7] can allow progressive load shedding instead of a complete blackout, ensuring that key loads remain powered.

In the developing world, many development-aid financing programs in the past decades focused on providing autonomous PV-battery systems, but did not include any provisions for long-term maintenance of these systems. This proved to be of high importance since lack of funds to exchange the battery banks was and still is one of the most common reasons for stranded non-operational autonomous systems in Sub-Saharan Africa [54]. The current trend is also to facilitate productive uses of energy applications while providing electrification to communities in order to increase economic activity and ultimately the income of the local population [55]. Agricultural loads such as milling for on-site production of flour, ice making, or water pumping coupled with a tank can be scheduled anytime throughout the day. This can further decrease the need for large battery banks, since optimal scheduling is feasible, increasing the applicability and cost-effectiveness of geothermal ORC engine 
use [56]. Finally, several different possibilities can be applied to finance an off-grid rural ORC system in a developing country, with the most commonly used options being private financing, financing through the power utility, government financing, and public-private partnerships [40].

Finally, as far as the environmental sustainability of the system is concerned, the geothermal ORC system needs a much lower capacity battery bank. Moreover, it is not oversized in terms of installed power, which is the reality of systems based solely on intermittent renewable energy sources. This has a direct positive impact in terms of sustainability in comparison with the rest of the investigated systems. As was presented in the introduction, there are concerns related to geothermal power production, but it has to be noted that these are also related to both the installed power of the system and the temperature of the geothermal water. In this case the ORC engine is of very low power and the temperature of the source is low $\left(\sim 100^{\circ} \mathrm{C}\right)$. Finally, $\mathrm{H}_{2} \mathrm{~S}$ and geothermal water effluent can be utilized in a sustainable way in agriculture-related activities around the served community as a fertilizer and for irrigation after pre-treatment.

\section{Conclusions}

This paper investigated the use of small-scale low-enthalpy geothermal power generation through an ORC engine in the APM topology. The availability of commercial small-scale $\left(<10 \mathrm{~kW}_{\mathrm{e}}\right)$ ORC engines operating at low temperatures $\left(\sim 100^{\circ} \mathrm{C}\right)$ is starting to increase, the costs have a potential to decrease, and due to the low complexity of these machines, they could be manufactured even in developing countries. The results of this paper show clearly that the use of these engines is very cost effective and competitive to PVs and wind turbines in microgrids technically, economically, and environmentally. The field of application of these results is immense and very crucial both for the developed and the developing world, contributing to the sustainable development of these communities. Follow-up work will include the investigation of the applications of an APM using low-enthalpy geothermal energy in Sub-Saharan Africa, encompassing productive uses of energy and household electrification.

Author Contributions: Conceptualization, G.K.; methodology, G.K. and D.M.; software, G.K.; validation, G.K., E.N., and D.M.; investigation, G.K.; resources, G.K. and E.N.; data curation, G.K. and E.N.; writing-original draft preparation, G.K.; writing - review and editing, E.N. and D.M.; visualization, G.K.; supervision, D.M. All authors have read and agreed to the published version of the manuscript.

Funding: This research received no external funding.

Conflicts of Interest: The authors declare no conflict of interest.

\section{Nomenclature}

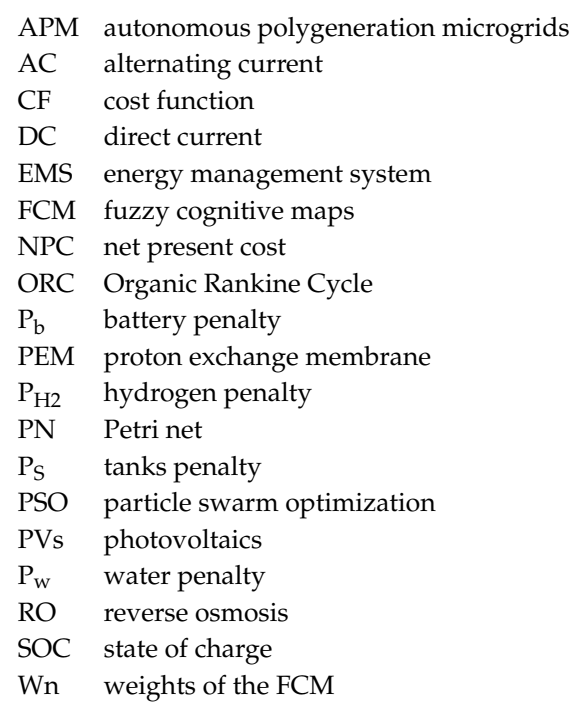




\section{References}

1. Manolakos, D.; Kosmadakis, G.; Ntavou, E.; Tchanche, B. Test results for characterizing two in-series scroll expanders within a low-temperature ORC unit under partial heat load. Appl. Therm. Eng. 2019, 163, 114389. [CrossRef]

2. Ntavou, E.; Kosmadakis, G.; Manolakos, D.; Papadakis, G.; Papantonis, D. Experimental testing of a small-scale two stage Organic Rankine Cycle engine operating at low temperature. Energy 2017, 141, 869-879. [CrossRef]

3. Kosmadakis, G.; Mousmoulis, G.; Manolakos, D.; Anagnostopoulos, I.; Papadakis, G.; Papantonis, D. Development of Open-Drive Scroll Expander for an Organic Rankine Cycle (ORC) Engine and First Test Results. Energy Procedia 2017, 129, 371-378. [CrossRef]

4. Kyriakarakos, G.; Dounis, A.I.; Rozakis, S.; Arvanitis, K.; Papadakis, G. Polygeneration microgrids: A viable solution in remote areas for supplying power, potable water and hydrogen as transportation fuel. Appl. Energy 2011, 88, 4517-4526. [CrossRef]

5. Kyriakarakos, G.; Dounis, A.I.; Arvanitis, K.; Papadakis, G. A fuzzy logic energy management system for polygeneration microgrids. Renew. Energy 2012, 41, 315-327. [CrossRef]

6. Kyriakarakos, G.; Dounis, A.I.; Arvanitis, K.; Papadakis, G. A fuzzy cognitive maps-petri nets energy management system for autonomous polygeneration microgrids. Appl. Soft Comput. 2012, 12, 3785-3797. [CrossRef]

7. Kyriakarakos, G.; Piromalis, D.D.; Dounis, A.I.; Arvanitis, K.; Papadakis, G. Intelligent demand side energy management system for autonomous polygeneration microgrids. Appl. Energy 2013, 103, 39-51. [CrossRef]

8. Karavas, C.-S.; Kyriakarakos, G.; Arvanitis, K.G.; Papadakis, G. A multi-agent decentralized energy management system based on distributed intelligence for the design and control of autonomous polygeneration microgrids. Energy Convers. Manag. 2015, 103, 166-179. [CrossRef]

9. Karavas, C.-S.; Arvanitis, K.; Papadakis, G. A Game Theory Approach to Multi-Agent Decentralized Energy Management of Autonomous Polygeneration Microgrids. Energies 2017, 10, 1756. [CrossRef]

10. Kofinas, P.; Dounis, A.; Vouros, G. Fuzzy Q-Learning for multi-agent decentralized energy management in microgrids. Appl. Energy 2018, 219, 53-67. [CrossRef]

11. Kyriakarakos, G.; Piromalis, D.D.; Arvanitis, K.; Dounis, A.I.; Papadakis, G. On battery-less autonomous polygeneration microgrids: Investigation of the combined hybrid capacitors/hydrogen alternative. Energy Convers. Manag. 2015, 91, 405-415. [CrossRef]

12. Karavas, C.-S.; Arvanitis, K.; Kyriakarakos, G.; Piromalis, D.D.; Papadakis, G. A novel autonomous PV powered desalination system based on a DC microgrid concept incorporating short-term energy storage. Sol. Energy 2018, 159, 947-961. [CrossRef]

13. Dimitriou, E.; Mohamed, E.S.; Kyriakarakos, G.; Papadakis, G. Experimental investigation of the performance of a reverse osmosis desalination unit under full- and part-load operation. Desalin. Water Treat. 2014, 53, 3170-3178. [CrossRef]

14. Beltran, H.; Ayuso, P.; Pérez, E. Lifetime Expectancy of Li-Ion Batteries used for Residential Solar Storage. Energies 2020, 13, 568. [CrossRef]

15. Haefliger, P.; Mathieu-Nolf, M.; Lociciro, S.; Ndiaye, C.; Coly, M.; Diouf, A.; Faye, A.L.; Sow, A.; Tempowski, J.; Pronczuk, J.; et al. Mass Lead Intoxication from Informal Used Lead-Acid Battery Recycling in Dakar, Senegal. Environ. Health Perspect. 2009, 117, 1535-1540. [CrossRef]

16. Chandrasekharam, D.; Bundschuh, J. Low-Enthalpy Geothermal Resources for Power Generation; CRC Press: Boca Raton, FL, USA, 2008.

17. Lund, J.W.; Boyd, T.L. Direct utilization of geothermal energy 2015 worldwide review. Geothermics 2016, 60, 66-93. [CrossRef]

18. Garcia, S.I.; Garcia, R.F.; Carril, J.C.; Garcia, D.I. A review of thermodynamic cycles used in low temperature recovery systems over the last two years. Renew. Sustain. Energy Rev. 2018, 81, 760-767. [CrossRef]

19. Kosmadakis, G.; Manolakos, D.; Papadakis, G. Experimental investigation of a low-temperature organic Rankine cycle (ORC) engine under variable heat input operating at both subcritical and supercritical conditions. Appl. Therm. Eng. 2016, 92, 1-7. [CrossRef] 
20. Lu, Y.; Roskilly, A.; Yu, X.; Tang, K.; Jiang, L.; Smallbone, A.; Chen, L.; Wang, Y. Parametric study for small scale engine coolant and exhaust heat recovery system using different Organic Rankine cycle layouts. Appl. Therm. Eng. 2017, 127, 1252-1266. [CrossRef]

21. Ismail, B.I. Introductory Chapter: Power Generation Using Geothermal Low-Enthalpy Resources and ORC Technology. In Renewable Geothermal Energy Explorations; IntechOpen: Rijeka, Croatia, 2019.

22. VanderMeer, J.B.; Mueller-Stoffels, M. Wind-Geothermal-Diesel Hybrid Micro-Grid Development: A Technical Assessment for Nome, AK. Master's Thesis, University of Oldenburg, Oldenburg, Germay, 2014.

23. Kaplan, U.; SFAR, R.; SHILON, Y. Small scale geothermal power plants with less than 5.0 MW capacity. Bull. Hydrogéol. 1999, 17, 433-440.

24. Welch, P.; Boyle, P.; Giron, M.; Sells, M. Construction and startup of low temperature geothermal power plants. Geotherm. Resour. Council Trans. 2011, 35, 1351-1356.

25. Schochet, D.N. Case histories of small scale geothermal power plants. In Proceedings of the 2000 World Geothermal Congress, Tohoku, Japan, 28 May-10 June 2000; pp. 2201-2204.

26. Bianchi, M.; Branchini, L.; De Pascale, A.; Melino, F.; Ottaviano, S.; Peretto, A.; Torricelli, N.; Zampieri, G. Performance and operation of micro-ORC energy system using geothermal heat source. Energy Procedia 2018, 148, 384-391. [CrossRef]

27. Welzl, M.; Heberle, F.; Brüggemann, D. Experimental evaluation of nucleate pool boiling heat transfer correlations for R245fa and R1233zd(E) in ORC applications. Renew. Energy 2020, 147, 2855-2864. [CrossRef]

28. Eyerer, S.; Dawo, F.; Wieland, C.; Spliethoff, H. Advanced ORC architecture for geothermal combined heat and power generation. Energy 2020, 205, 117967. [CrossRef]

29. Manolakos, D.; Papadakis, G.; Kyritsis, S.; Bouzianas, K. Experimental evaluation of an autonomous low-temperature solar Rankine cycle system for reverse osmosis desalination. Desalination 2007, 203, 366-374. [CrossRef]

30. Shortall, R.; Davidsdottir, B.; Axelsson, G. Geothermal energy for sustainable development: A review of sustainability impacts and assessment frameworks. Renew. Sustain. Energy Rev. 2015, 44, 391-406. [CrossRef]

31. Finster, M.; Clark, C.; Schroeder, J.; Martino, L. Geothermal produced fluids: Characteristics, treatment technologies, and management options. Renew. Sustain. Energy Rev. 2015, 50, 952-966. [CrossRef]

32. Boswell, C.C.; Friesen, D.K. Elemental sulfur fertilizers and their use on crops and pastures. Nutr. Cycl. Agroecosyst. 1993, 35, 127-149. [CrossRef]

33. Shah, M.; Sircar, A.; Varsada, R.; Vaishnani, S.; Savaliya, U.; Faldu, M.; Vaidya, D.; Bhattacharya, P. Assessment of geothermal water quality for industrial and irrigation purposes in the Unai geothermal field, Gujarat, India. Groundw. Sustain. Dev. 2019, 8, 59-68. [CrossRef]

34. Tartière, T.; Astolfi, M. A World Overview of the Organic Rankine Cycle Market. Energy Procedia 2017, 129, 2-9. [CrossRef]

35. Enogia. ORC ENO-10LT. Available online: http://enogia.com/wp/ (accessed on 20 June 2020).

36. Zuccato Energia. ULH-Series ORC Modules. Available online: http://www.zuccatoenergia.it/en/company/our-firm (accessed on 20 June 2020).

37. Infinity Turbine LLC. IT10 System Plans. Available online: https://infinityturbine.com/it10-system-plans/ (accessed on 20 June 2020).

38. Orcan. Orcan Power Generation-EP 05.15. Available online: https://www.orcan-energy.com/en/applicationspower-generation.html (accessed on 20 June 2020).

39. Budisulistyo, D.; Krumdieck, S.P. Thermodynamic and economic analysis for the pre-feasibility study of a binary geothermal power plant. Energy Convers. Manag. 2015, 103, 639-649. [CrossRef]

40. Baral, S.; Kim, D.; Yun, E.; Kim, K.C. Energy, Exergy and Performance Analysis of Small-Scale Organic Rankine Cycle Systems for Electrical Power Generation Applicable in Rural Areas of Developing Countries. Energies 2015, 8, 684-713. [CrossRef]

41. Lowitzsch, J.; Hoicka, C.; Van Tulder, F. Renewable energy communities under the 2019 European Clean Energy Package-Governance model for the energy clusters of the future? Renew. Sustain. Energy Rev. 2020, 122, 109489. [CrossRef]

42. Antics, M.; Sanner, B. Status of geothermal energy use and resources in Europe. In Proceedings of the Proceedings European Geothermal Congress, Unterhaching, Germany, 30 May-1 June 2007.

43. IEA. World Energy Outlook 2017; OECD Publishing: Paris, France, 2017. [CrossRef] 
44. Teklemariam, M. Overview of Geothermal resource utilization and potential in East African rift system. In Proceedings of the 30th Anniversary Workshop of UNU-GTP, Reykjavik, Entebbe, Uganda, 20-22 November 2008.

45. Bloomquist, G.; Niyongabo, P.; El-Halabi, R.; Löschau, M. The AUC/KFW Geothermal Risk Mitigation Facility (GRMF)-A Catalyst for East African Geothermal Development. Geotherm. Resour. Council Trans. 2012, 36, 4.

46. Dagnachew, A.G.; Lucas, P.L.; Hof, A.F.; Gernaat, D.E.; De Boer, H.-S.; Van Vuuren, D.P. The role of decentralized systems in providing universal electricity access in Sub-Saharan Africa-A model-based approach. Energy 2017, 139, 184-195. [CrossRef]

47. Delgarm, N.; Sajadi, B.; Kowsary, F. Multi-objective optimization of the building energy performance: A simulation-based approach by means of particle swarm optimization (PSO). Appl. Energy 2016, 170, 293-303. [CrossRef]

48. Singh, P.; Manjaree, P.; Srivastava, L. PSO-Based Optimization of Levelized Cost of Energy for Hybrid Renewable Energy System. In Algorithms for Intelligent Systems; Springer Science and Business Media LLC: Berlin/Heidelberg, Germany, 2020; pp. 31-42.

49. Steca. Steca PF 166-H. Available online: https://www.steca.com/index.php?Steca-PF-166-H-240-H-en (accessed on 20 June 2020).

50. Kyriakarakos, G. Renewable Energy Autonomous Polygeneration Smartgrids Optimized with Soft Computing Techniques; Agricultural University of Athens: Athens, Greece, 2013.

51. Zoulias, E.; Glöckner, R.; Lymberopoulos, N.; Tsoutsos, T.; Vosseler, I.; Gavalda, O.; Mydske, H.; Taylor, P. Integration of hydrogen energy technologies in stand-alone power systems analysis of the current potential for applications. Renew. Sustain. Energy Rev. 2006, 10, 432-462. [CrossRef]

52. Karytsas, C.; Mendrinosa, D.; Radoglou, G. The current geothermal exploration and development of the geothermal field of Milos island in Greece. GHC Bull 2004, 25, 17-21.

53. Laboratory, TRotUoCt L.B.N. GenOpt. Available online: http://simulationresearch.lbl.gov/GO/ (accessed on 3 December 2020).

54. Graffy, E.A. Sparking a Worldwide Energy Revolution: Social Struggles in the Transition to a Post-Petrol World-By Kolya Abramsky. Rev. Policy Res. 2012, 29, 309-311. [CrossRef]

55. Kyriakarakos, G.; Papadakis, G. Microgrids for Productive Uses of Energy in the Developing World and Blockchain: A Promising Future. Appl. Sci. 2018, 8, 580. [CrossRef]

56. Kyriakarakos, G.; Balafoutis, A.; Bochtis, D. Proposing a Paradigm Shift in Rural Electrification Investments in Sub-Saharan Africa through Agriculture. Sustainability 2020, 12, 3096. [CrossRef]

Publisher's Note: MDPI stays neutral with regard to jurisdictional claims in published maps and institutional affiliations.

(C) 2020 by the authors. Licensee MDPI, Basel, Switzerland. This article is an open access article distributed under the terms and conditions of the Creative Commons Attribution (CC BY) license (http://creativecommons.org/licenses/by/4.0/). 